\title{
PENGELOLAAN HUMAS DI LEMBAGA PENDIDIKAN MENUJU LEMBAGA PENDIDIKAN YANG UNGGUL
}

\author{
Nunung Yuliani \\ SDN Kebon Sirih 01 Pagi Jakarta \\ yuliani1975nuuggmail.com \\ Wahyu Bagja Sulfemi \\ STKIP Muhammadiyah Bogor \\ wahyubagja@gmail.com
}

\section{PENDAHULUAN}

Sekolah adalah didalam, oleh dan untuk masyarakat. Program sekolah hanya dapat berjalan lancar apabila mendapat dukungan masyarakat. Oleh karena itu Pimpinan sekolah perlu terus menerus membina hubungan yang baik antara sekolah dan masyarakat. Sekolah perlu banyak memberi informasi kepada masyarakat tentang program-prgoram dan problemproblem yang dihadapi, agar masyarkat mengetahui dan memahami masalah-masalah yang dihadapi sekolah. Dari pemahaman dan pengertian ini dapat dihadapkan adanya umpan balik yang sangat berguna bagi pengembangan program sekolah lebih lanjut dan diharapkan pula tumbuhnya rasa simpati masyarakat terhadap program-program sekolah, yang dapat mengundang partisipasi yang aktif masyarkat.

Lembaga pendidikan sesungguhnya melaksanakan fungsi rangkap terhadap masyarakat yaitu memberi layanan dan sebagai agen pembaru atau penerang. Dikatakan fungsi layanan karena ia melayani kebutuhan-kebutuhan masyarakat, dan disebut fungsi pemimpin sebab ia memimpin masyarakat disertai dengan penemuan-penemuannya untuk memajukan kehidupan masyarakat. Hubungan kerja sama lembaga dengan masyarakat, mengikuti perubahan-perubahan lingkungan dengan pendekatan situasional, memungkinkan lembaga itu tetap berdiri. Sebab ia berada dan hidup bersama masyarakat dan sekaligus menjadi penerang atau inovator bagi masyarakat. Inilah yang perlu diusahakan oleh para manajer pendidikan.

Lingkungan pendidikan adalah segala sesuatu yang ada dan terjadi di sekeliling proses pendidikan itu berlangsung yang terdiri dari manusia, binatang, tumbuh-tumbuhan, dan benda-benda mati. Keempat kelompok benda-benda lingkungan pendidikan itu ikut berperan dalam rangka usaha setiap siswa mengembangkan dirinya. Tetapi manajemen 
pendidikan menaruh perhatiannya terutama kepada lingkungan yang berwujud manusia yaitu masyarakat.

Perhatian manajer terpusat kepada kelompok manusia atau masyarakat lingkungannya. Sebab hanya masyarakatlah yang bisa diajak berbicara tentang hal-hal yang menyangkut pendidikan, termasuk menunjukkan apa saja yang ada di sekitar mereka yang bisa dipakai bahan untuk belajar. Anggota masyarakat inilah teman manajer yang bisa diajak merencanakan, mengkoordinasi, dan bahkan dapat ikut mengontrol jalannya pendidikan.

Pendidikan adalah tanggung jawab bersama antara pemerintah, orang tua, dan masyarakat. Hal ini mengisyaratkan bahwa lembaga pendidikan hendaknya tidak menutup diri, melainkan selalu mengadakan kontak hubungan dengan dunia luar yaitu orang tua dan masyarakat sekitar sebagai teman penanggung jawab pendidikan. Dengan kedua kelompok inilah sekolah bekerja sama mengatasi problem-problem pendidikan yang muncul dan memajukannya.

Dengan demikian tampaklah bahwa lembaga pendidikan itu bukanlah badan yang berdiri sendiri dalam membina pertumbuhan dan perkembangan putra-putra bangsa, melainkan ia merupakan suatu bagian yang tidak terpisahkan dari masyarakat yang luas. Ia sebagai sistem terbuka, yang selalu mengadakan kerja sama dengan warga masyarakat lainnya, secara bersama-sama membangun di bidang pendidikan. Hal ini sangat mungkin dilakukan sebab masyarakat sangat sadar akan manfaat pendidikan sebagai modal utama dalam membangun dan memajukan bangsa termasuk masyarakat atau keluarga itu sendiri. Mereka pada umumnya menaruh perhatian besar terhadap pendidikan putra-putranya.

Bila lembaga pendidikan terbuka bagi para siswa, maka begitu pula hendaknya bagi warga masyarakat. Bukan hanya bagi warga masyarakat yang ingin belajar, tetapi juga bagi mereka yang menaruh perhatian terhadap pendidikan. Citra masyarakat akan pendidikan perlu diperhatikan oleh lembaga pendidikan. Semangat dan itikad baik mereka perlu disalurkan, diterima sebagai teman seperjuangan dalam memajukan pendidikan.

\section{PEMBAHASAN}

Berbicara tentang humas pasti ingatan kita akan tertuju pada hal yang berhubungan dengan komunikasi, konfrensi pers, informasi, public relation. Pokoknya secara gampang diibaratkan sebagai penyampaian segala informasi. Menurut kamus Fund and Wagnel Pengertian Humas adalah segenap kegiatan dan teknik/kiat yang digunakan organisasi atau individu untuk menciptakan atau memelihara suatu sikap dan tanggapan yang baik dari pihak luar terhadap keberadaan dan aktivitasnya. Sedangkan pengertian Humas dalam Pendidikan 
adalah Rangkaian pengelolaan yang berkaitan dengan kegiatan hubungan lembaga pendidikan dengan masyarakat (orang tua murid) yang dimaksudkan untuk menunjang proses belajar mengajar di lembaga pendidikan bersangkutan (Anggoro, 2001).

Berdasarkan definisi diatas pegertian humas secara umum adalah fungsi yang khas antara organisasi dengan publiknya, atau dengan kata lain antara lembaga pendidikan dengan warga di dalam (guru, karyawan, siswa) dan warga dari luar (wali siswa, masyarakat, institusi luar, patner sekolah) Dalam konteks ini jelas bahwa humas atau public relation (PR) adalah termasuk salah satu elemen yang penting dalam suatu organisasi kelompok ataupun secara individu. Adapun pengertian manajemen humas adalah suatu proses dalam menangani perencanaan, pengorganisasian, mengkomunikasikan serta pengkoordinasian yang secara serius dan rasional dalam upaya pencapaian tujuan bersama dari organisasi atau lembaga yang diwakilinya. Untuk merealisasikan itu semua banyak hal yang harus dilakukan oleh humas dalam suatu lembaga pendidikan (Nasution, 2006).

Tugas pokok hubungan sekolah dengan masyarakat dalam pendidikan antara lain:

1. Memberikan informasi dan menyampaikan ide atau gagasan kepada masyarakat atau pihak-pihak lain yang membutuhkannya.

2. Membantu pemimpin yang karena tugas-tugasnya tidak dapat langsung memberikan informasi kepada masyarakat atau pihak-pihak yang memerlukannya.

3. Membantu pemimpin mempersiapkan bahan-bahan tentang permasalahan dan informasi yang akan disampaikan atau yang menarik perhatian masyarakat pada saat tertentu.

4. Melaporkan tentang pikiran-pikiran yang berkembang dalam masyarakat tentang masalah pendidikan.

5. Membantu kepala sekolah bagaimana usaha untuk memperoleh bantuan dan kerja sama.

6. Menyusun rencana bagaimana cara-cara memperoleh bantuan untuk kemajuan pelaksanaan pendidikan (Suryosubroto: 2004).

Mengenai tujuan hubungan sekolah dan masyarakat (orang tua murid), leslie merumuskan tujuan organisasi perkumpulan antara guru dan masyarakat (orang tua murid), adalah sebagai berikut: a) Untuk mengembangkan pengertian masyarakat (orang tua murid) tentang tujuan dan kegiatan pendidikan di sekolah. b) Untuk memperlihatkan bahwa rumah dan sekolah bekerja sama dalam rangka mencapai tujuan pendidikan anak disekolah. c) Untuk membari fasilitas pertukaran informasi antara orang tua dan guru yang kemudian mempunyai dampak terhadap pemecahan pendidikan anak. d) Perolehan opini masyarakat tentang sekolah dijadikan perencanaan untuk pertemuan dengan orang tua dalam rangka 
untuk kebutuhan murid-murid. e) Untuk membantu pertumbuhan dan perkembangan pribadi anak (Indrafachrudi: 1994).

Sedangkan menurut Mulyasa (2007: 50), tujuan dari hubungan sekolah dengan masyarakat adalah: (1) memajukan kualitas pembelajaran dan pertumbuhan peserta didik; (2) memperkokoh tujuan serta meningkatkan kualitas hidup dan penghidupan masyarakat; dan (3) menggairahkan masyarakat untuk menjalin hubungan dengan sekolah.

Jenis hubungan sekolah dan masyarakat itu dapat digolongkan menjadi 3 jenis, yaitu:a) Hubungan edukatif, ialah hubungan kerja sama dalam hal mendidik murid, antara guru di sekolah dan orang tua di dalam keluarga. Adanya hubungan ini dimaksudkan agar tidak terjadi perbedaan prinsip atau bahkan pertentangan yang dapat mengakibatkan keraguraguan pendirian dan sikap pada diri anak. b) Hubungan kultural, yaitu usaha kerja sama antara sekolah dan masyarakat yang memungkinkan adanya saling membina dan mengembangkan kebudayaan masyarakat tempat sekolah itu berada. Untuk itu diperlukan hubungan kerja sama antara kehidupan di sekolah dan kehidupan dalam masyarakat. Kegiatan kurikulum sekolah disesuaikan dengan kebutuhan dan tuntutan perkembangan masyarakat. Demikian pula tentang pemilihan bahan pengajaran dan metode-metode pengajarannya. c) Hubngan institusional, yaitu hubungan kerja sama antara sekolah dengan lembaga-lembaga atau instansi resmi lain, baik swasta maupun pemerintah, seperti hubungan kerja sama antara sekolah satu dengan sekolah-sekolah lainnya, kepala pemerintah setempat, ataupun perusahaan-perusahaan Negara, yang berkaitan dengan perbaikan dan perkembangan pendidikan pada umumnya (Purwanto, 2005: 193)

Ada sejumlah tehnik yang kiranya dapat diterapkan lembaga pendidikan, tehniktehnik tersebut dapat dikelompokkan menjadi tiga, yaitu tehnik tertulis, tehnik lisan, dan tehnik peragaan, tehnik elektronik. Pertama. Tehnik Tertulis. Hubungan antara sekolah dan masyarakat dapat dilakukan secara tertulis, cara tertulis yang dapat digunakan meliputi: 1) Buku kecil pada permulaan tahun ajaran Buku kecil pada permulaan tahun ajaran baru ini isinya dijelaskan tentang tata tertib, syarat-syarat masuk, hari-hari libur, hari-hari efektif. Kemudian buku kecil ini dibagikan kepada orang tua murid, hal ini biasanya dilaksanakan di taman kanak-kanak (TK). 2) Pamflet. Pamflet merupakan selebaran yang biasanya berisi tentang sejarah lembaga pendidikan tersebut, staf pengajar, fasilitas yang tersedia, dan kegiatan belajar. Pamphlet ini selain di bagikan ke wali murid juga bias di sebarkan ke masyarakat umum, selain untuk menumbuhkan pengertian masyarakat juga sekaligus untuk promosi lembaga (Indrafachrud: 1994). 3) Berita kegiatan murid. Berita ini dapat dibuat sederhana mungkin pada selebaran kertas yang berisi informasi singkat tentang kegiatan- 
kegiatan yang dilakukan di sekolah atu pesantren. Dengan membacanya orang tua murid mengetahui apa yang terjadi di lembaga pendidikan tersebut, khususnya kegiatan yang dilakukan murid. 4) Catatan berita gembira. Tehnik ini sebenarnya mirip dengan berita kegiatan murid, keduanya sama-sama ditulis dan disebarkan ke orang tua. Hanya saja catatan berita gembira ini berisi tentang keberhasilan seoran murid. Berita tersebut ditulis di selebaran kertas dan disampaikan kepada wali murid atau bahkan disebarkan ke masyarakat. 5) Buku kecil tentang cara membimbing anak. Dalam rangka menciptakan hubungan yang harmonis dengan orang tua, kepala sekolah atau guru dapat membuat sebuah buku kecil yang sederhana yang berisi tentang cara membimbing anak yang efektif, kemudian buku tersebut diberikan kepada orang tua murid (Bafadhol, 2005: 63).

Kedua Tehnik Lisan. Hubungan sekolah dengan masyarakat dapat juga lisan, yaitu: 1) Kunjungan rumah. Dalam rangka mengadakan hubungan dengan masyarakat, pihak sekolah dapat mengadakan kunjungan ke rumah wali murid, warga atupun tokoh masyarakat. Melalui kunjungan rumah ini guru akan mengetahui masalah anak dirumahnya. Apabila setiap anak diketahui problemnya secara totalitas, maka program pendidikan akan lebih mudah direncanakan untuk disesuaikan dengan minatnya. Hal ini akan memperlancar mancapai tujuan program pendidikan sekolah tersebut (Indrafachrud, 1994: 69). 2) Panggilan orang tua. Selain mengadakan kunjungan ke rumah, pihak sekolah sesekali juga memanggil orang tua murid datang ke sekolah. Setelah dating, mereka diberi penjelasan tentang perkembangan pendidikan di lembaga tersebut. Mereka juga perlu diberi penjelasan khusus tentang perkembangan pendidikan anaknya. 3) Pertemuan. Dengan tehnik ini berarti sekolah mengundang masyarakat dalam acara pertemuan khusus untuk membicarakan masalah atau hambatan yang dihadapi sekolah. Pertemuan ini sebaiknya diadakan pada waktu tertentu yang dapat dihadiri oleh semua pihak yang diundang. Sebelum pertemuan dimulai acaranya disusun terlebih dahulu. Oleh karena itu, dalam setiap akan mengadakan pertemuan sebaiknya dibentuk panitia penyelenggara. c) Tehnik Peragaan. Hubungan sekolah dengan masyarakat dapat dilakukan dengan cara mengundang masyarakat melihat peragaan yang diselenggarakan sekolah. Peragaan yang diselenggarakan bias berupa pameran keberhasilan murid. Misalkan di TK menampilkan anak-anak bernyanyi, membaca puisi, atau biasanya di pesantren ketika mengadakan pengajian ditampilkan santri-santri yang hafal nadhom alfiyah. Pada kesempatan itu kepala sekolah atau guru atau juga pengasuh kalau di pondok pesantren dapat menyampaikan program-program peningkatan mutu pendidikan dan juga masalah atau hambatan yang dihadapi dalam merealisasikan program-program itu (Bafadhol, 2005: 69). d) Tehnik Elektronik. Seiring dengan perkembangan teknologi elektronik maka dalam 
mengakrabkan sekolah dengan orang tua murid dan masyarakat pihak sekolah dapat menggunakan sarana elektronik, misalkan dengan telpon, televisi, ataupun radio, sekaligus sebagai sarana untuk promosi pendidikan. Hubungan lembaga pendidikan dan masyarakat adalah suatu proses komunikasi antara lembaga pendidikan dan masyarakat dengan tujuan untuk meningkatkan pemahaman masyarakat terhadap kebutuhan dan praktek pendidikan dan pada akhirnya bekerjasama untuk meningkatkan kualitas pendidikan di lembaga pendidikan (Maisyaroh, 2004:3)

Menurut kamus Fund and Wagnel Pengertian Humas adalah segenap kegiatan dan teknik/kiat yang digunakan organisasi atau individu untuk menciptakan atau memelihara suatu sikap dan tanggapan yang baik dari pihak luar terhadap keberadaan dan aktivitasnya. Sedangkan pengertian Humas dalam Pendidikan adalah Rangkaian pengelolaan yang berkaitan dengan kegiatan hubungan lembaga pendidikan dengan masyarakat (orang tua murid) yang dimaksudkan untuk menunjang proses belajar mengajar di lembaga pendidikan bersangkutan (Ardiansyah: 2011).

Berdasarkan definisi di atas pengertian humas secara umum adalah fungsi yang khas antara organisasi dengan publiknya, atau dengan kata lain antara lembaga pendidikan dengan warga di dalam (guru, karyawan, siswa) dan warga dari luar (wali siswa, masyarakat, institusi luar, patner sekolah). Dalam konteks ini jelas bahwa humas atau Public Relation (PR) adalah termasuk salah satu elemen yang penting dalam suatu organisasi kelompok ataupun secara individu. Adapun pengertian manajemen humas adalah suatu proses dalam menangani perencanaan, pengorganisasian, mengkomunikasikan serta pengkoordinasian yang secara serius dan rasional dalam upaya pencapaian tujuan bersama dari organisasi atau lembaga yang diwakilinya.

Tujuan hubungan sekolah dan masyarakat (orang tua murid), Leslie (dalam Indrafachrudi: 1994) merumuskan tujuan organisasi perkumpulan antara guru dan masyarakat (orang tua murid), adalah sebagai berikut:

1. Untuk mengembangkan pengertian masyarakat (orang tua murid) tentang tujuan dan kegiatan pendidikan di sekolah.

2. Untuk memperlihatkan bahwa rumah dan sekolah bekerja sama dalam rangka mencapai tujuan pendidikan anak di sekolah.

3. Untuk membari fasilitas pertukaran informasi antara orang tua dan guru yang kemudian mempunyai dampak terhadap pemecahan pendidikan anak.

4. Perolehan opini masyarakat tentang sekolah dijadikan perencanaan untuk pertemuan dengan orang tua dalam rangka untuk kebutuhan murid-murid. 
5. Untuk membantu pertumbuhan dan perkembangan pribadi anak.

Penyusunan Program Hubungan Sekolah dan Masyarakat (Humas)

Menurut Nasution (2006) untuk menentukan strategi dalam kegiatan humas pada lembaga pendidikan yang akan dilakukan terlebih dahulu memperhitungkan:

1. "Tujuan" apa yang hendak dicapai sesuai dengan perencanaan yang telah diperhitungkan dengan baik oleh pihak-pihak terlibat dalam manajemen lembaga pendidikan;

2. "Strategi" apa dan bagaimana yang dipergunakan dalam perencanaan;

3. "Program kerjanya" apa yang akan dilakukan dan dijabarkan sesuai langkah-langkah yang telah dijadwalkan;

4. Menentukan "anggaran" atau "dana" yang sudah dipersiapkan, serta "daya" sebagai pendukung yang bersifat khusus.

Strategi humas ini adalah suatu cara alternatif optimal yang dipilih untuk melaksanakan atau ditempuh guna mencapai tujuan humas dalam kerangka suatu rencana humas. Untuk melaksanakan strategi humas menurut Ruslan (2001) dalam Nasution (2006) harus diupayakan sebagai berikut;

1. Menempatkan posisi humas dekat dengan pimpinan lembaga pendidikan agar humas mengetahui secara jelas dan rinci mengenai pola perencanaan, kebijakan, keputusan yang diambil, visi dan arah tujuan lembaga pendidikan bersangkutan, agar tidak terjadi kesalahan dalam penyampaian pesan dan informasi yang berasal dari lembaga pendidikan kepada masyarakat;

2. Humas dalam memberikan informasi mewakili lembaga pendidikan tersebut dapat dipertegas tentang batas-batas wewenang dan tanggungjawab dalam memberikan keterangan (sebagai juru bicara);

3. Pimpinan atau staf humas selalu diikutsertakan menghadiri setiap rapat atau pertemuan pada tingkat pimpinan agar dapat mengetahui secara langsung dengan tepat tentang "latar belakang" suatu proses perencanaan, kebijaksanaan, arah dan hingga tujuan organisasi yang hendak dicapai, baik dalam jangka pendek maupun dalam jangka panjang;

4. Agar humas humas diberi fungsi koordinasi berhubungan secara langsung dan segera dengan pimpinan puncak (rektor/direktur/kepala sekolah), tanpa melalui perantara pejabat/bagian lain;

5. Humas harus bertindak secara proaktif dan dinamis serta fleksibel sebagai narasumber atau mengatur saluran komunikasi baik ke dalam maupun ke luar;

6. Humas berperan melakukan tindakan mulai dari memonitor, merekam, menganalisis, menelaah, hingga mengevaluasi setiap reaksi feedback; 
7. Humas dapat memberikan sumbang saran, ide, dan rencana/program kerja kehumasan untuk memperbaiki/mempertahankan nama baik, kepercayaan, dan citra perusahaan terhadap publiknya.

Berdasarkan strategi yang harus diupayakan para praktisi, humas di lembaga pendidikan diperlukan beberapa pendekatan agar strategi tersebut bisa berjalan dengan lancar antara lain; pendekatan kemasyarakatan, pendekatan persuasif, sosial, kerjasama yang harmonis, dan koordinasi.

Tujuan umum dari merencanakan program kerja dalam manajemen Humas adalah bagaimana upaya menciptakan hubungan harmonis antara lembaga pendidikan yang diwakilinya dengan masyarakat atau stakeholder, agar tujuan yang diharapkan dapat terwujud. Hal itu berkaitan dengan kemampuan staf Humas dalam manajemen teknis dan sebagai keterampilan manajerial, serta penuh konsentrasi dari pihak praktisi Humas untuk mengelola program kerja Humas dalam upaya pencapaian tujuan atau sasaran sebagaimana yang direncanakan.

Langkah-langkah kegiatan Humas dalam merencanakan program kerja menurut Rosady (2001) dalam Nasution (2006) ada beberapa tahapan sebagai berikut;

1. Menganalisis perilaku umum dan hubungan organisasi terhadap lingkungan;

2. Menentukan dan memahami secara benar perilaku tiap-tiap kelompok terhadap organisasi;

3. Menganalisis tingkat opini publik, baik ke dalam maupun ke luar;

4. Mengantisipasi kecenderungan masalah yang potensial, kebutuhan, dan kesempatan;

5. Menentukan formulasi dan merumuskan kebijakan;

6. Merencanakan alat atau cara yang sesuai untuk meningkatkan atau mengubah perilaku kelompok masyarakat sasaran;

7. Menjalankan dan melaksanakan aktivitas sesuai dengan program yang direncanakan;

8. Menerima umpan balik untuk dievaluasi, kemudian mengadakan penyesuaian yang diperlukan.

Semua kegiatan Humas terlebih dahulu hendaknya disusun melalui rencana program kerja Humas dalam program rutin (jangka pendek) dan program kerja insedentil (jangka panjang). Dalam implementasi program kerja harus dilaksanakan secara terus menerus dan kronologis. Adapun program kerja yang akan dilaksanakan menurut Nasution (2006) dapat dibagi menjadi 2 kegiatan yakni: a). Program Kerja Rutin. Program kerja rutin adalah kegiatan yang dilaksanakan secara terus menerus dan kronologis. B). Program Kerja Insidentil. Program kerja insidentil adalah kegiatan yang dilaksanakan pada periode tertentu. 
Program kerja ini pada prinsipnya membantu pelaksanaan semua program kerja yang dilaksanakan kantor pusat dalam bidang komunikasi dan publikasi untuk semua warga sekolah/organisasi pendidikan maupun masyarakat luas.

Ada banyak teknik pelaksanaan program hubungan lembaga pendidikan dan masyarakat. Agar penerapan teknik berhasil, lembaga pendidikan perlu memperhatikan komitmen masyarakat terhadap pendidikan. Kalau komitmen masyarakat masih belum muncul maka perlu dibangkitkan komitmennya. Masyarakat perlu disentuh hatinya agar mereka merasa perlu pendidikan. Tidak ada Negara maju tanpa keberadaan lembaga pendidikan yang berkualitas. Lembaga pendidikan yang berkualitas tentunya membutuhkan uluran tangan dari berbagai pihak, baik dari segi biaya, tenaga maupun pemikiran yang cemerlang demi kemajuan lembaga pendidikan. Kalau kegiatan pembelajaran ingin berkualitas, maka sumber belajar juga harus lengkap, guru harus berkualitas. Semua itu membutuhkan biaya yang tidak sedikit, pepatah jawa mengatakan "jer basuki mawa bea". Setiap kegiatan yang berkualitas butuh biaya. Kalau sesuatu ingin baik maka perlu disediakan biaya yang banyak.

Sebenarnya meskipun biaya pendidikan mahal, masyarakat tidak akan dirugikan. Pada dasarnya kalau pendidikan berkualitas maka yang memetik hasilnya adalah masyarakat. Misalnya, lembaga pendidikan yang menghasilkan lulusan yang memiliki kompetensi dalam bidang penguasaan teknologi informasi, maka pihak pemakai lulusan akan memperoleh keuntungan. Tenaga yang mampu dan terampil dapat meningkatkan efektivitas dan efisiensi perusahaan atau pengguna lulusan yang lain.

Untuk itu hal yang perlu dilakukan lembaga pendidikan adalah meyakinkan kepada masyarakat bahwa pendidikan yang berkualitas itu penting dan perlu terwujud pada setiap lembaga pendidikan. Langkah awal yang dapat dilakukan agar masyarakat merasakan perlunya pendidikan yang berkualitas yaitu penerapan pendekatan budaya. Dalam pendekatan budaya masyarakat diajak untuk mengetahui dan mengenal pendidikan, meyakini manfaat pendidikan, dan percaya terhadap mutu pendidikan. Dengan proses ini diharapkan masyarakat merasa bahwa pendidikan mutlak diperlukan.

Menurut Maisyaroh (2004:23-24) teknik penyelenggaraan hubungan lembaga pendidikan dan masyarakat dapat dikelompokkan menjadi empat, yaitu teknik pertemuan kelompok, teknik tatap muka, observasi dan partisipasi, surat menyurat dengan berbagai pihak yang dapat dikaitkan dengan penyelenggaraan pendidikan.

1. Teknik Pertemuan Kelompok. Teknik pertemuan kelompok dapat berupa diskusi, seminar, lokakarya, sarasehan, rapat dan sebagainya. Yang dilibatkan dalam pertemuan kelompok 
adalah guru, staf tata usaha, tokoh masyarakat, staf dari instansi yang terkait dengan penyelenggaraan program pendidikan, pengguna lulusan, guru/dosen dari lembaga pendidikan lain, dokter, dan sebagainya. Ragam unsur yang dilibatkan didalam kegiatan ini tergantung dari tema yang sedang dibahas. Tema yang dibahas bisa berkaitan dengan peningkatan kemampuan staf sekolah, peningkatan kemampuan siswa, pengembangan sarana dan prasarana sekolah, optimalisasi perlibatan masyarakat dalam penyelenggaraan pendidikan dan juga dikembangkan tema yang menarik sesuai kondisi yang ada.

1. Teknik Tatap Muka. Teknik tatap muka dilakukan antara pihak lembaga pendidikan dan masyarakat secara individual. Pihak lembaga pendidikan dapat berkunjung ke rumah siswa yang menghadapi masalah. Pihak lembaga pendidikan dapat memanggil orangtua atau wali siswa yang bermasalah atau siswa yang memiliki kemampuan lebih dan perlu pembinaan bersama agar kemampuannya dapat berkembang secara maksimal.

2. Obvserasi dan Partisipasi. Observasi dan partisipasi masyarakat terhadap pelaksanaan pendidikan perlu dilakukan. Sekolah perlu member kesempatan kepada masyarakat untuk menunjungi, mengobservasi, dan berpartisipasi dalam kegiatan sekolah. Orangtua siswa dapat mengunjungi sekolah untuk mengobservasi proses belajar siswa. Orangtua memiliki keterampilan tertentu dapat membantu guru mengajar. Dalam hal ini orangtua sebagai narasumber pembahasan materi tertentu. Melalui kegiatan ini diharapkan masyarakat mengetahui secara langsung hambatan dan faktor pendukung penyelenggaraan pendidikan, masyarakat mengetahui keberhasilan lembaga pendidikan, akhirnya masyarakat diharapkan mau membantu pelaksanaan pendidikan di lembaga pendidikan

3. Surat Menyurat dengan Berbagai Pihak yang Terkait dengan Penyelenggaraan Pendidikan. Surat menyurat sudah lazim dilakukan oleh setiap lembaga pendidikan. Selain biaya yang cukup murah, teknik ini dianggap mampu dilakukan setiap lembaga yang sederhana maupun lembaga yang sudah besar perkembangannya.

Dipihak lain, secara teoritis Layanan Riset Pendidikan dan Asosiasi Nasional Kepala Pendidikan Dasar di Alexandria merumuskan berbagai teknik untuk meningkatkan keterlibatan berbagai pihak dalam menyelenggarakan pendidikan (dalam Maisyaroh, 2004:23). Teknik yang dimaksud dapat dikemukakan dengan asosiasi:

1. Layanan masyarakat. Pihak lembaga pendidikan mempelajari kebutuhan masyarakat, melihat dan menganalisis apa yang bisa dilakukan lembaga pendidikan untuk membantu memecahkan masalah dan memenuhi kebutuhan masyarakat.

2. Program pemanfaatan alumni sekolah. Para alumni dapat dilibatkan dalam kegiatan sekolah, misalnya menjadi pembicara dalam kegiatan seminar-seminar di sekolah, 
keberhasilannya dalam menempuh karir dapat diinformasikan kepada peserta didik agar bersemangat dalam belajarnya, dapat menentukan karir, dan meningkatkan kemampuannya sehingga bisa sukses seperti kakak kelasnya yang telah lulus.

3. Masyarakat sebagai model. Masyarakat menjadi model peserta didik di sekolah terutama masyarakat yang telah berhasil dalam kehidupannya.

4. Pemberian kesempatan kepada masyarakat. Lembaga pendidikan memberi kesempatan kepada masyarakat secara sukarela untuk membantu kegiatan lembaga pendidikan.

5. Pengiriman pembicara. Anggota staf lembaga pendidikan yang berminat diberi kesempatan untuk mempromosikan program dan prestasi lembaga pendidikan ke masyarakat.

6. Masyarakat sebagai sumber informasi. Pihak lembaga pendidikan menanyakan kepada anggota masyarakat tentang isu-isu hangat terkait dengan pengembangan lembaga, hasilnya dibuat semacam rekomendasi untuk pengembangan lembaga pendidikan.

7. Diskusi Panel. Siswa, ortu siswa, staf sekolah dan pekerja yang lain, anggota masyarakat mengadakan pertemuan untuk menindak lanjuti kegiatan lembaga pendidikan agar semua usaha yang telah dilakukan dapat dirasakan manfaatnya oleh semua pihak.

Untuk menggambarkan keadaan sekolah kepada masyarakat ada beberapa cara atau metode yang lain. Gambaran tersebut diharapkan tercipta hubungan yang lebih erat antara sekolah dengan masyarakat. Menurut Indrafachrudi (dalam Soetopo dan Soemanto, 1982: 246) ada 11 teknik yang dapat dilakukan untuk memberikan gambaran tentang sekolah yang perlu diketahui oleh masyarakat, yaitu:

1. Laporan Kepada Orangtua Murid. Laporan yang diberikan oleh sekolah kepada masyarakat berisi laporan tentang kemajuan anak, aktivitas anak di sekolah, kegiatan sekolah sendiri, dan segala sesuatu yang terjadi di sekolah sehubungan dengan pendidikan anak. Laporan ini dapat dilakukan setiapsemester. Laporan tersebut tidak berupa angka-angka akan tetapi menyangkut informasi yang bersifat diagnosik. Artinya dalam laporan tersebut dicantumkan juga kelebihan dan kelemahan anak, disertai dengan jalan pemecahan yang kiranya dapat dilakukan oleh orangtua dalam ikut membantu kesuksesan belajar anak.

2. Bulletin Bulanan. Bulletin bulanan dapat diusahakan oleh guru, staf sekolah dan para orangtua yang dapat diterbitkan satu bulan sekali. Isi bulletin sekolah ini adalah tentang kegiatan sekolah, artikel-artikel guru dan juga murid, pengumuman-pengumuman sekolah berita-berita masyarakat yang perlu diketahui sekolah dan sebagainya. Di samping bulletin, sekolah dapat pula menerbitkan "Booklet" yaitu buku kecil yang diberikan 
kepada keluarga yang anaknya sekolah di sekolah tersebut. Isi "Booklet” adalah petunjuk cara belajar di sekolah yang bersangkutan, fasilitas sekolah, kurikulum yang dipakai, keadaan sekolah dan sejarahnya. Pengurus sekolah dan pengurus OSIS, kemajuan dan aktivitas sekolah selama ini dan program kerja pada saat itu.

3. Penerbitan Surat Kabar. Apabila dimungkinkan, sekolah dapat menerbitkan surat kabar sekolah. Isinya menyangkut segala aspek yang menunjang kesuksesan program pendidikan. Artikel-artikel yang dimuat harus berkaitan dengan dunia pendidikan sesuai dengan bidang yang dipelajari peserta didik. Berita-berita yang dimuat hendaknya juga berita-berita yang memiliki nilai didik.

4. Pameran Sekolah. Pameran sekolah merupakan metode yang sangat efektif untuk memberikan gambaran tentang keadaan sekolah dengan berbagai aktivitasnya. Masyarakat dapat melihat secara langsung keadaan sekolah dengan mengunjungi pameran tersebut. Tempat penyelenggaraan pameran dapat di dalam atau di luar kelas yaitu di halaman sekolah. Bahkan dapat juga dapat dilakukan di luar sekolah. Tentu yang terakhir ini memerlukan pengelolaan yang lebih rumit. Barang-barang yang dapat dipamerkan dapat berupa hasil karya siswa dan guru, alat-alat peraga dan hasil panenan kebun atau sawah (bila ada).

5. Open House. "Open House" merupakan suatu metode mempersilakan masyarakat yanng berminat untuk meninjau sekolah serta mengobservasi kegiatan dan hasil kerja murid dan guru yang diadakan pada waktu yang telah terjadwal. Pada saat itulah masyarakat dapat melihat secara langsung proses belajar mengajar yang berlangsung di sekolah. Dari gambaran ini masyarakat dapat memberikan penilaian atas pelaksanaan pendidikan di sekolah tersebut. Masyarakat juga dapat mengontrol sekolah dengan memberikan bantuan kepada sekolah baik berupa material maupun spirit, karena mereka merasa ikut bertanggungjawab atas pendidikan anak-anaknya di sekolah, walaupun tanggungjawab masyarakat ini tidak terumuskan secara formal.

6. Kunjungan Ke Sekolah (School Visitation). Kunjungan orang tua murid ke sekolah pada saat pelajaran berlangsung yang dimaksudkan agar para orangtua murid berkesempatan melihat anak-anaknya pada waktu mangikuti pelajaran. Di samping itu orang tua dapat melihat kegiatan anak di laboratorium, di bengkel atau di kebun. Kunjungan orangtua ini dapat dilakukan oleh para orangtua sewaktu-waktu, sehingga mereka dapat melihat kewajaran yang terjadi di sekolah itu.

7. Kunjungan Ke Rumah Murid (Home Visitation). Kunjungan ke rumah murid dilakukan untuk melihat latar belakang kehidupan murid di rumah. Penerapan metode ini akan 
mempererat hubungan antara sekolah dengan orang tua murid, di samping itu dapat menjalin silaturahim antara guru dengan orangtua murid. Masalah-masalah yang dihadapi murid di sekolah dapat dibicarakan secara kekeluargaan dan persahabatan intim. Kunjungan ke rumah orangtua murid harus direncanakan dan harus mengemban policy sekolah. Jadi tidak boleh dilakukan di luar kepentingan anak didik.

8. Melalui Penjelasan Oleh Staf Sekolah. Kepala sekolah hendaknya berusaha agar semua personel sekolah turut aktif mengambil bagian dalam penyuksesan program hubungan sekolah dengan masyarakat. Para personel sekolah dapat memberikan penjelasan kepada masyarakat tentang kebijakan sekolah, organisasi sekolah dan semua kegitan sekolah. Kepala sekolah dapat menambahkan loyalitas para staf dengan mengikutsertakan mereka dalam setiap kegiatan dan menghargai prestasi yang telah mereka capai.

9. Gambaran Keadaan Sekolah Melalui Murid. Murid dapat juga mendorong untuk memberikan informasi kepada masyarakat tentang keadaan sekolah. Jangan sampai murid-murid menyebarkan isu-isu yang tidak baik mengenai sekolah.

10. Melaui Media Elektronik. Media elektronik mempunyai daya yang kuat dalam menyebarkan pengaruh informasi yang disiarkan. Melalui media elektronik ini masyarakat akan lebih mengenal situasi dan kondisi perkembangan sekolah. Melalui media elektronik ini dapat menyampaikan berita-berita dan pengumuman yang berkaitan dengan penyelenggaraan pendidikan, termasuk apabila ada permohonan sumbangan dari pihak sekolah. Media elektronik dapat berupa televisi, radio, telepon, handphone, internet, email, website dan lain-lain.

11. Laporan Tahunan. Laporan tahunan disusun oleh kepala sekolah untuk diberikan kepada penilik sekolah atau kepada Kantor Departemen P dan K kecamatan yang mewadahinya atau kepada atasan langsungnya. Isi laporan tahunan tersebut mencakup kegiatan yang telah dilakukan, kurikulum, personalia, anggaran dan situasi murid.

Menurut Buchori (dalam Suparlan, 2005), Sekolah tidak dapat dikatakan sebagai suatu lembaga sosial yang berdiri sendiri, terlepas dari lembaga-lembaga sosial lain. Sekolah harus dipandang sebagai suatu bagian yang tidak dapat dipisahkan dari masyarakat yang ada di sekitarnya, baik masyarakat lokal, maupun masyarakat daerah atau masyarakat nasional.

Menurut Anwaruhamka (2010), pembangunan merupakan proses terus menerus untuk mencapai kesempurnaan. Pembangunan di Indonesia mencakup berbagai sektor salah satu diantaranya adalah sektor pendidikan. Peranan sektor pendidikan dalam mempersiapkan sumber daya tersebut diatas tidak dapat diabaikan. Program pendidikan harus berorientasi pada kebutuhan pasar kerja. Demikian pula produk yang dihasilkan oleh dunia usaha 
merupakan konsumsi masyarakat luas. Dengan demikian proses pelatihan akan memberi arti pada pencapaian tujuan pendidikan nasional.

Dengan kebijaksanaan Dinas Pendidikan nasional tentang pendekatan Pendidikan dengan Sistem Ganda sebagai pola utama penyelenggaraan Kurikulum Sekolah Menengah Kejuruan (SMK), merupakan salah satu upaya untuk meningkatkan kualitas tamatan agar lebih sesuai dengan tuntutan kebutuhan. Pembangunan Nasional pada umumnya, dan kebutuhan ketenaga kerjaan pada khusunya, sebagai bagian tak terpisahkan dari kebijaksanaan Link and Macth yang berlaku bagi semua jenis jenjang pendidikan di Indonesia. Munculnya gagasan Link and Macth (keterkaitan dan kesepadanan) ternyata telah membuka peluang bagi pihak pelaksana pendidikan khususnya Pendidikan Menengah Kejuruan untuk memungkinkan bekerja sama dengan Dunia Usaha dalam membina dan mengembangkan potensi di lapangan.

Link and Macth juga memberi kesempatan bagi peserta didik Sekolah Menengah Kejuruan untuk mengembangkan kreatifitas belajar pada wahana pendidikan yang lebih realistis. Pihak Sekolah Menengah Kejuruan harus dapat memanfaatkan Dunia Usaha ini sebagai wahana pelatihan yang paling efektif bagi pembentukan ketrampilan dan sikap profesional para lulusan.

Dengan adanya kesepakatan kerjasama antara pihak sekolah dengan Dunia Usaha maka Kegiatan Belajar Mengajar (KBM) para peserta didik di Sekolah Menengah Kejuruan akan memperoleh pengalaman yang sangat berharga sebagai persiapan memasuki bursa kerja. Proses kegiatan Belajar Mengajar seperti ini disebut Pendidikan Sistem Ganda.

Pada prinsipnya Pendidikan Sistem Ganda adalah kerja sama dengan Dunia Usaha/Dunia Industri yaitu saling membantu, saling mengisi dan saling melengkapi untuk meraih keuntungan bersama. Selagi Pendidikan Sistem Ganda tidak menjadi beban Dunia Usaha/Dunia Industri, kerja sama tersebut dapat ditumbuh kembangkan sekaligus sebagai wujud atau peran serta Dunia Usaha/Dunia Industri dalam pembangunan nasional pada umumnya dan pelaksanaan Pendidikan Sistem Ganda khusunya.

Dalam pelaksanaan Pendidikan Sistem Ganda guru merupakan kunci keberhasilan pendidikan formal sebab secara dinamis tuntutan mutu lulusan Sekolah Menengah Kejuruan dipengaruhi oleh kualitas gurunya. Perkembangan teknologi di Dunia Usaha dan Dunia Industri sangat pesat maka dirasakan lulusan Sekolah Menengah Kejuruan masih perlu secara dinamis ditingkatkan kemampuannya agar memenuhi kesempatan kerja.

Disadari bahwa penyiapan Sumber Daya Manusia yang tangguh sebagai modal pembangunan yang produktif adalah menjadi tanggung jawab bersama pemerintah, 
masyarakat dan keluarga. Maka dukungan semua pihak untuk menyelenggarakan pendidikan di Sekolah Menengah Kejuruan yang dapat menghasilkan lulusan yang berkualitas sesuai dengan misinya yang diperlukan. Kreatifitas guru dalam mempersiapkan bahan ajar sangat menentukan kebutuhan pengetahuan sebagai kesiapan diri pada peserta didiknya untuk memasuki lapangan kerja dan kehidupan masyarakat dikemudian hari.

Penguatan sinergi antara keluarga, sekolah, dan masyarakat (terutama masyarakat DUDI), diharapkan dapat ikut mendorong dan meningkatkan mutu layanan pendidikan yang ada di daerah. Perlu kita ketahui bahwa syarat utama yang diperlukan untuk membangun kepercayaan dari pihak DUDI, tidak lain adalah adanya transparansi, demokratiasi, dan akuntabelitas yang dilakukan oleh semua komponen pendidikan, termasuk di dalamnya Dewan Pendidikan, sebagai lembaga mandiri, wadah peran serta masyarakat (Suparlan, 2005)

\section{PENUTUP}

Demikianlah sedikit uraian tentang manajemen humas di sekolah, dan ini tidak berlaku di sekolah formal saja namun juga bisa diterapkan di Lemabaga Pendidikan. Pendidikan adalah tanggung jawab bersama antara pemerintah, orang tua, dan masyarakat. Hal ini mengisyaratkan bahwa lembaga pendidikan hendaknya tidak menutup diri, melainkan selalu mengadakan kontak hubungan dengan dunia luar yaitu orang tua dan masyarakat sekitar sebagai teman penanggung jawab pendidikan. Dengan kedua kelompok inilah sekolah bekerja sama mengatasi problem-problem pendidikan yang muncul dan memajukannya.

Lembaga pendidikan sesungguhnya melaksanakan fungsi rangkap terhadap masyarakat yaitu memberi layanan dan sebagai agen pembaru atau penerang. Dikatakan fungsi layanan karena ia melayani kebutuhan-kebutuhan masyarakat, dan disebut fungsi pemimpin sebab ia memimpin masyarakat disertai dengan penemuan-penemuannya untuk memajukan kehidupan masyarakat. Hubungan kerja sama lembaga dengan masyarakat, mengikuti perubahan-perubahan lingkungan dengan pendekatan situasional, memungkinkan lembaga itu tetap berdiri. Sebab ia berada dan hidup bersama masyarakat dan sekaligus menjadi penerang atau inovator bagi masyarakat. Inilah yang perlu diusahakan oleh para manajer pendidikan

Dengan adanya manajeman Humas menciptakan hubungan harmonis antara lembaga pendidikan yang diwakilinya dengan masyarakat atau stakeholder, agar tujuan yang diharapkan dapat terwujud yang berkaitan dengan kemampuan staf Humas dalam manajemen teknis dan sebagai keterampilan manajerial, serta penuh konsentrasi sehingga pencapaian tujuan atau sasaran sebagaimana yang direncanakan. 
Tentunya tulisan ini masih sangat jauh untuk mengungkap secara detail dan sempurna tentang manajemen humas. Untuk itu penulis yakin makalah ini masih membutuhkan banyak koreksi dan masukan. Sebagai penutup penulis berharap makalah ini dapat memberikan manfaat kepada pembaca.

\section{REFERENSI}

Anwaruhamka. 2010. Peran dunia Usaha dan Dunia Industr (Online) (http://www.anwaruhmkablogspot.com/2010/10/PERAN DUNIA USAHA DAN DUNIA INDUSTRI (DUDI) DALAM DUNIA PENDIDIKAN _ Anwaruhamka20's Blog.html).

Ardiansyah , M. Asrori. 2011. Teknik-teknik Humas Pendidikan. (Online) (http://www.majalahpendidikan.com/2011/04/teknik-teknik-humaspendidikan_22.html).

Bafadhol, Ibrahim. 2005. Dasar-dasar Manajemen dan Supervisi Taman Kanak-kanak. Jakarta: PT Bumi aksara.

Fajartriani, Tia dan Sulfemi, Wahyu Bagja. (2014). Pengaruh Motivasi Kerja Guru dan Iklim Organisasi Terhadap Kinerja Guru SMA Negeri di Kecamatan Cigudeg. Edutecno. $8(1), 17-26$.

Indrafachrudi, Soekarto. 1994. Bagaimana Mengakrabkan Sekolah dengan Orang tua Murid dan Masyarakat. Malang: IKIP.

Maisyaroh. 2004. Buku Ajar Manajemen Hubungan Masyarakat. Malang: Universitas Negeri Malang.

Mulyasa, Endang. 2007. Manajemen Berbasis Sekolah. Bandung: PT Remaja Rosdakarya.

Nasution, Zulkarnain. 2006. Manajemen Humas di Lembaga Pendidikan. Malang: UMM Press.

Purwanto, Ngalim. 2005. Administrasi dan Supervisi Pendidikan. Bandung: PT. Remaja. Rosdakarya.

Sudirman, Sudirman \& Sulfemi, Wahyu Bagja. 2010. Korelasi Antara Konsep Diri Guru dengan Profesionalisme Guru di SMA Negeri 1 Pamijahan Kabupaten Bogor. Edutecno 2 (2), 10-19

Soetopo, Hendyat dan Wasty Soemanto. 1982. Pengantar Operasional Administrasi Pendidikan. Surabaya: Usaha Nasional.

Suparlan. 2005. Peran Dunia Usaha dan Dunia Industri dalam bidang Pendidikan (Online) (http://www.suparlan.com/ Peran Dunia Usaha dan Dunia Industri dalam Bidang Pendidikan _ Suparlan.html).

Sulfemi, Wahyu Bagja. 2015. Challenges Of Indonesian Teacher Competence in dealing with Asean Economic Cummunity (AEC). Engglis Forum. 1 (1), 69-79.

Sulfemi, Wahyu Bagja. 2016. Perundang-Undangan Pendidikan. Bogor : Program Studi Administrasi Pendidikan STKIP Muhammadiyah Bogor 
Sulfemi, Wahyu Bagja. 2016. Kompetensi Profesionalisme Guru Indonesia dalam

Menghadapi MEA. Prosiding Seminar Nasional STKIP Muhammadiyah Bogor. 1 (1), 62-77.

Sulfemi, W. B. 2019. Modul Pembelajaran Perundang-Undangan Pendidikan. Bogor : STKIP Muhammadiyah Bogor

Sulfemi, Wahyu Bagja. 2018. Manajemen Pendidikan Berbasis Multi Budaya. Bogor : STKIP Muhammadiyah Bogor

Sulfemi, Wahyu Bagja. 2018. Modul Manajemen Pendidikan Non Formal. Bogor: STKIP Muhammadiyah Bogor

Sulfemi, Wahyu Bagja. 2019. Asosiatif Layanan Tenaga Perpustakaan Sekolah Dengan Motivasi Membaca Siswa di Kabupaten Bogor. Edutecno. 19 (2), 1-10.

Suryosubroto. 2004. Manajemen Pendidikan Di Sekolah. Jakarta: PT Rineka Cipta.

Yusfiriadi, Yusfiriadi, \& Sulfemi, Wahyu Bagja. 2011. Pemberdayaan Unit Produksi Melalui Pendekatan Manajemen Stratejik di SMK Pertiwi Kabupaten Bogor. Edutecno. 3 (1), 1-10.

Suprihatin, Y., \& Sulfemi, W. B. 2013. Kemampuan Menulis Deskripsi. Bogor: STKIP Muhammadiyah Bogor. 